University for Business and Technology in Kosovo

UBT Knowledge Center

Nov 2nd, 11:30 AM - 11:45 AM

\title{
Standard Energy Audit In The Residential Buildings - A Case Study In A Residential Apartment In Street "New Kalabria" In Pristina
}

\author{
Mehmet Qelaj \\ M.ZH.E \\ Flamur Bidaj \\ Nafije Gashi \\ Studio e projektimit LINKS 4 \\ Ali Muriqi \\ Driton Ademj \\ Studio e projektimit LINKS 4
}

See next page for additional authors

Follow this and additional works at: https://knowledgecenter.ubt-uni.net/conference

Part of the Architecture Commons

\section{Recommended Citation}

Qelaj, Mehmet; Bidaj, Flamur; Gashi, Nafije; Muriqi, Ali; Ademj, Driton; and Nushi, Violeta, "Standard Energy Audit In The Residential Buildings - A Case Study In A Residential Apartment In Street "New Kalabria" In Pristina" (2013). UBT International Conference. 26.

https://knowledgecenter.ubt-uni.net/conference/2013/all-events/26

This Event is brought to you for free and open access by the Publication and Journals at UBT Knowledge Center. It has been accepted for inclusion in UBT International Conference by an authorized administrator of UBT Knowledge Center. For more information, please contact knowledge.center@ubt-uni.net. 


\section{Presenter Information}

Mehmet Qelaj, Flamur Bidaj, Nafije Gashi, Ali Muriqi, Driton Ademj, and Violeta Nushi 


\title{
Standard Energy Audit In The Residential Buildings - A Case Study In A Residential Apartment In Street „New Kalabria" In Pristina
}

\author{
Mehmet Qelaj; Flamur Bidaj; Nafije Gashi; Ali Muriqi; Driton Ademi; Violeta Nushi
}

\begin{abstract}
In an energy audit, the main goal is to achieve energy savings, identify opportunities for savings, the measures for saving energy efficient, prepared the report on energy saving measures. The energy auditis aimed adequate knowledge on the current state of energy consumption in buildings and identify opportunities in energy consumption and cost effective reporting of results. The data to be analyzed are: energy bills (electricity, fuel) for the audit period, for the last three years (and/or next year), building plans and studies and its energy installations electromechanical characteristics building/structure and operation of the apparatus/equipment basic climate data for the period in which the auditis being done. This paper will present an analysis of the overall energy audit standard for residential dwellings in Pristina
\end{abstract}

Key words: audit, efficiency, electricity consumption, specific consumption

\section{Layout and apartment on the seventh floor}

The object is located in the district, "New Calabria" in Pristina and new construction. This building consists of eight floors, ground floor and basement. Flats which is audited found on the seventh floor, overlooking the South. Its area is 62.7 square meters, has sufficient insight and also has sufficient lighting.

The present paper will appear auditing standard apartment and found the specific consumption of electricity and thermal energy and has determined that a need to take measures or not. If yes, should be taken, if not, it is consumption remains current.

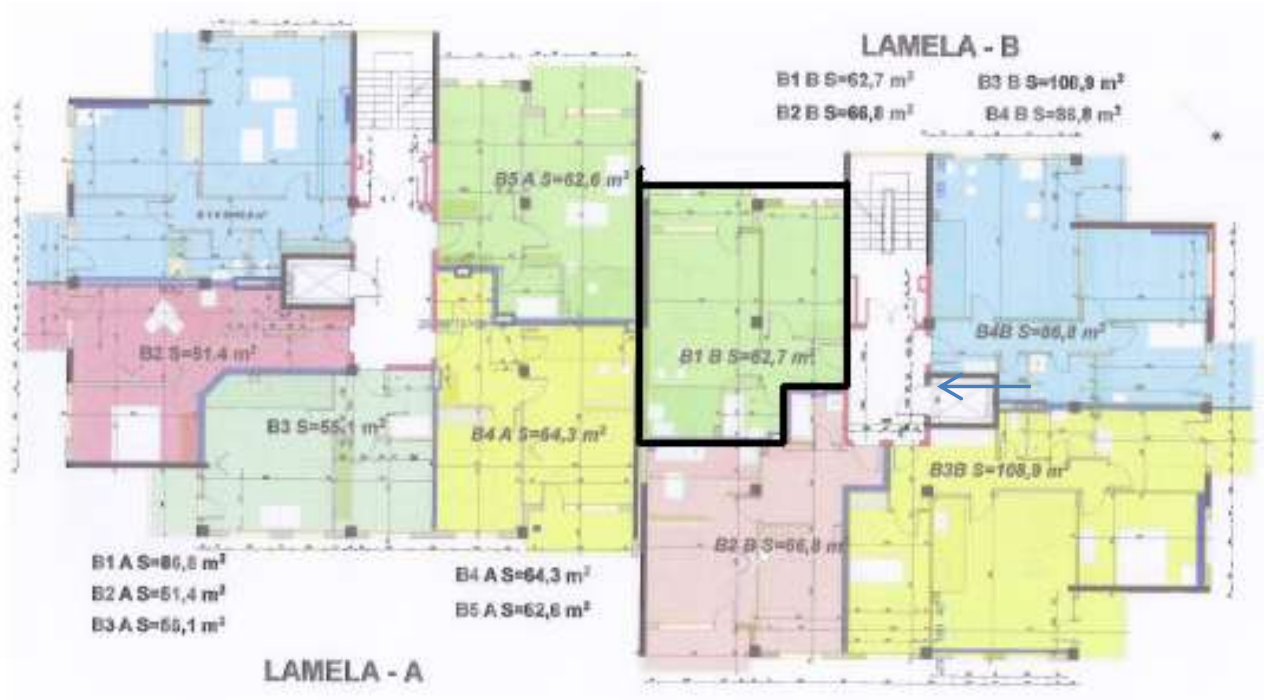

a) 


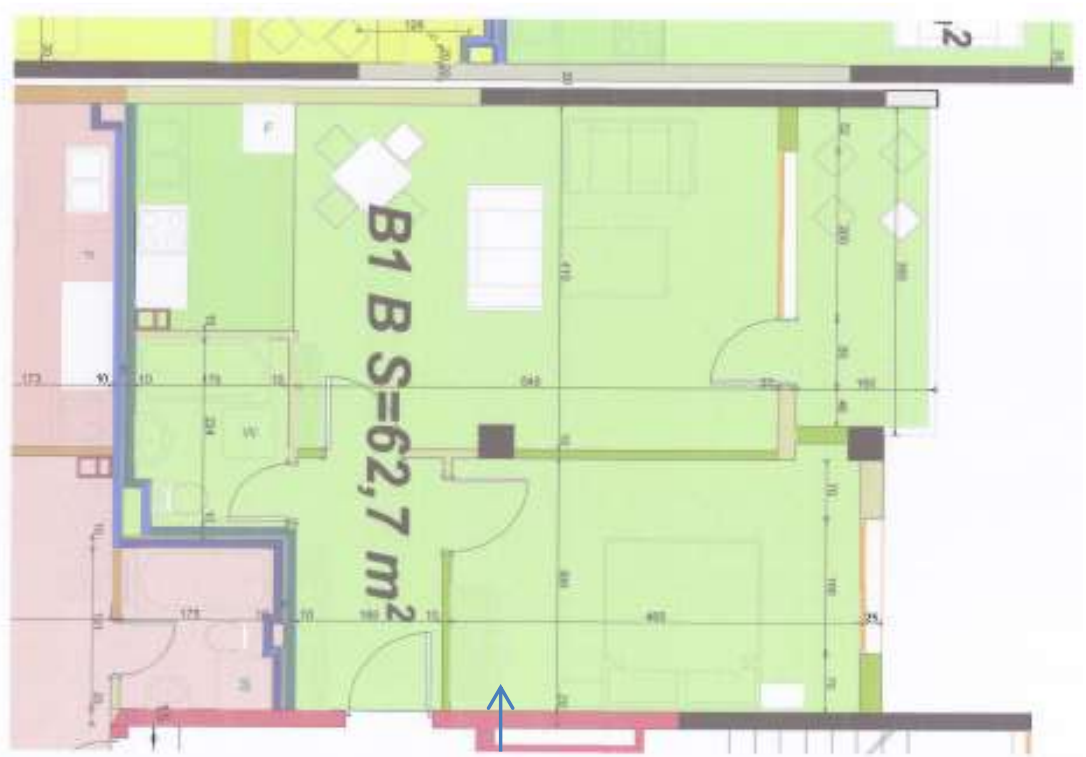

b)

Figure 1: The layout of all floors in two entries, A and B - the first object

Table 1: Data of the auditing apartment

\section{Building auditing}

Date of audit

The person interviewed

\begin{tabular}{ll}
\hline Year of construction & 2009 \\
Type of building & More storey residential structure \\
Type of construction & Skeletal system \\
Number of floors complete & 10 (suteren, ground floors 8) \\
Apartament & Located on the seventh floor \\
General state sanitary Technical & Good \\
Residents & \\
Accessibility & The permanent \\
Number of users & 3 \\
\end{tabular}

Building First, First Entry - Residential

\section{Apartment - Floor VII, No. 1}

owner 


\subsection{Energy For Heating And Other Energy Use}

The heating system is installed in a building central system, based on its own boiler.

Table 2 Interior comfort for working spaces

\begin{tabular}{|c|c|c|}
\hline Heating System & \multicolumn{2}{|c|}{$\begin{array}{l}\text { Own central system, but the function is just a radiator. } \\
\text { Heating system at home there, but the feature is not is sued } \\
\text { due to high costs of electricity and is replaced by a small } \\
\text { electric heater, which spends very little electricity with a } \\
\text { capacity of } 2[\mathrm{~kW}] \text {. }\end{array}$} \\
\hline Subject to burns & \multicolumn{2}{|c|}{ Electricity } \\
\hline \multicolumn{3}{|l|}{$\begin{array}{l}\text { The average annual } \\
\text { consumption }\end{array}$} \\
\hline \multirow[t]{4}{*}{ system } & Heating season & $\begin{array}{l}\text { October } 15-15 \text { th April. } \\
\text { Is not involved in } \\
\text { TERMOKOS }\end{array}$ \\
\hline & & $\begin{array}{l}\text { heating, but the } \\
\text { network is ready } \\
\text { whenever you connect } \\
\text { to the district heating } \\
\text { system }\end{array}$ \\
\hline & operates & Operates \\
\hline & Termination of heat (justification) & Not due to saving \\
\hline The state of comfort & \multicolumn{2}{|c|}{$\begin{array}{l}\text { Good, because it is new construction and is comfortable } \\
\text { enough, both in terms of heat, as well as the lighting. }\end{array}$} \\
\hline
\end{tabular}

Electricity is used for lighting, cooking equipment, sanitary, but the key is to heat it. Calculation of electricity is made by the expression:

$$
V V=P \cdot t=U \cdot l \cdot t
$$

$V V$ - Electricity, $\mathrm{P}$ - Power, U-voltage, I - Intensity, T - Time.

Terms of comfort for heating, lighting, cooling and ventilation are calculated based on the setting of standards and conditions for a unified system in Kosovo under legislation and applicable international standards described above in the first chapter:

Table 3: Geometric Data

\begin{tabular}{|c|c|c|c|c|c|c|c|c|c|}
\hline \multicolumn{10}{|c|}{ The main geometrical data } \\
\hline No & Wall & $\begin{array}{l}\text { The } \\
\text { peri } \\
\text { mete } \\
\mathrm{r} \text { of } \\
\text { the } \\
\text { wall } \\
\text { [m] }\end{array}$ & $\begin{array}{l}\text { The } \\
\text { height } \\
\text { of the } \\
\text { wall } \\
\text { [m] }\end{array}$ & $\begin{array}{l}\text { The } \\
\text { height of } \\
\text { the wall } \\
\text { [m] net }\end{array}$ & $\begin{array}{l}\text { Windo } \\
\text { Ws } \\
{\left[\mathbf{m}^{2}\right]}\end{array}$ & $\begin{array}{l}\text { Exterio } \\
\mathbf{r} \text { doors } \\
{\left[\mathrm{m}^{2}\right]}\end{array}$ & $\begin{array}{l}\text { Area } \\
{\left[\mathbf{m}^{2}\right]}\end{array}$ & $\begin{array}{l}\text { Apart } \\
\text { ment } \\
\text { area } \\
{\left[\mathrm{m}^{2}\right]}\end{array}$ & $\begin{array}{l}\text { The } \\
\text { volume } \\
\text { of } \\
\text { Apart } \\
\text { ment } \\
{\left[\mathrm{m}^{3}\right]}\end{array}$ \\
\hline 1 & Foreign & 8.2 & 3 & 2.8 & 5.32 & 1.68 & 24.6 & 62.7 & 175.56 \\
\hline 2 & Corridor & 15.3 & 3 & 2.8 & & 2.1 & 45.9 & 62.7 & 175.56 \\
\hline 3 & Neighbors & 8.8 & 3 & 2.8 & & & 26.4 & 62.7 & 175.56 \\
\hline \multicolumn{5}{|c|}{ Total } & $\mathbf{0}$ & $\mathbf{0}$ & 96.9 & 62.7 & 175.6 \\
\hline
\end{tabular}

2.2 Situation Standardized Calculations 
Table 4: Data on state standardized apartment

\begin{tabular}{|c|c|c|c|}
\hline & $\begin{array}{l}\text { Cons umption } \\
\text { situation } \\
\text { standardized } \\
\text { comfort }[\mathrm{kWh}]\end{array}$ & $\begin{array}{l}\text { Cons umption } \\
\text { after EE } \\
\text { measures }[\mathrm{kWh}]\end{array}$ & Saving [kWh] \\
\hline The exterior walls & 200.84 & 200.84 & 0.00 \\
\hline The walls of the corridor & 1506.28 & 1151.00 & 355.28 \\
\hline Adjoining walls & 1369.00 & 1369.00 & 0.00 \\
\hline Window & 0.00 & 0.00 & 0.00 \\
\hline Doors & 566.60 & 566.60 & 0.00 \\
\hline Tiles on earth & 402.59 & 402.59 & 0.00 \\
\hline Ceiling Tiles & 0.00 & 0.00 & 0.00 \\
\hline Transmission loss & 0.00 & 0.00 & 0.00 \\
\hline Infiltrate loss & 4045.31 & 3690.03 & 355.28 \\
\hline Yield heating system & 681.15 & 681.15 & 0.00 \\
\hline ENERGY FOR HEATING & 4726.46 & 4371.18 & 355.28 \\
\hline $\begin{array}{l}\text { The surface of the } \mathrm{S}=62.7 \\
{\left[\mathrm{~m}^{2}\right]}\end{array}$ & 75.38 & 69.71 & 5.67 \\
\hline
\end{tabular}

Power transmission losses for different elements of the coat are expressed in the following figure.

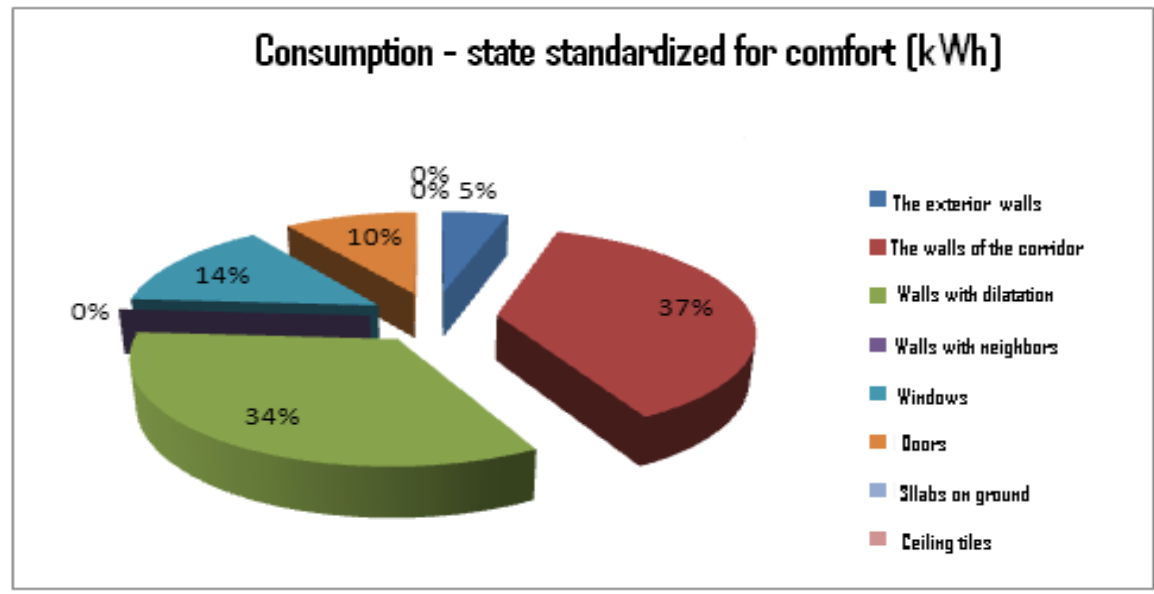

Fig. 2 Losses in transmission

The chart above shows that the greatest losses are in the walls of the corridor, which included the dilatation wall. This is an indicator that there should intervene in isolation, but would technically be possible only by stairs wall insulation. Energy losses from the floor and ceiling are zero because the apartment has other apartments above and below, which we assumed that the standard heated $20^{\circ} \mathrm{C}$. Also, the wall that separates losses neighbor, for the same reason, the losses are calculated as zero.

\subsection{Current Loads For Heating}


Table 5: Data of electricity for heating

\begin{tabular}{llllllc}
\hline No & Equipments & Quantity & $\begin{array}{l}\text { The } \\
\text { power } \\
\text { unit } \\
{[\mathbf{k W} / \mathbf{h}]}\end{array}$ & $\begin{array}{l}\text { Overall } \\
\text { power } \\
{[\mathbf{k W}]}\end{array}$ & $\begin{array}{l}\text { Annual } \\
\text { of use }\end{array}$ & $\begin{array}{c}\text { hours } \\
\text { Annual } \\
\text { cons umption } \\
{[\mathbf{k W h}]}\end{array}$ \\
\hline 1 & $\begin{array}{l}\text { Electric } \\
\text { Heating }\end{array}$ & 1 & 1.5 & 1.5 & 480 & 720 \\
\hline
\end{tabular}

Table 6: Data for sanitary hot water

\begin{tabular}{|c|c|c|c|c|c|c|}
\hline No & Equipments & Quantity & $\begin{array}{l}\text { The } \\
\text { power } \\
\text { unit } \\
{[\mathrm{kW} / \mathrm{h}]}\end{array}$ & $\begin{array}{l}\text { Overall } \\
\text { power } \\
{[k \mathbf{W}]}\end{array}$ & $\begin{array}{l}\text { Annual } \\
\text { hours of } \\
\text { use }\end{array}$ & $\begin{array}{l}\text { Annual } \\
\text { cons umption } \\
{[\mathrm{kWh}]}\end{array}$ \\
\hline \multirow[t]{2}{*}{1} & Boiler 801 & 1 & 2 & 2 & 1480 & 2960 \\
\hline & & & & & Total & 2960 \\
\hline
\end{tabular}

\subsection{Current Loads}

Table 7: Data on household appliances

\begin{tabular}{lllllll}
\hline No & Equipments & Quantity & $\begin{array}{l}\text { The } \\
\text { power } \\
\text { unit } \\
{[\mathbf{k W} / \mathbf{h}]}\end{array}$ & $\begin{array}{l}\text { Overall } \\
\text { power } \\
{[\mathbf{k W}]}\end{array}$ & $\begin{array}{l}\text { Annual } \\
\text { hours } \\
\text { of use }\end{array}$ & $\begin{array}{l}\text { Annual } \\
\text { cons umption } \\
{[\mathbf{k W h}]}\end{array}$ \\
& & 0.35 & 0.35 & 1200 & 420 \\
\hline 1 & Freezer & 1 & 1 & 1 & 365 & 365 \\
2 & $\begin{array}{l}\text { Equipment for boiling } \\
\text { water, coffee }\end{array}$ & 1 & & & & \\
3 & Frieze & 1 & 0.5 & 0.5 & 750 & 375 \\
4 & Baking oven & 1 & 2 & 2 & 200 & 400 \\
5 & Hair dryer & 1 & 1 & 1 & 50 & 50 \\
6 & TV & 1 & 0.08 & 0.08 & 1825 & 146 \\
7 & Ironing & 1 & 2 & 2 & 120 & 240 \\
8 & Washing & 1 & 2.5 & 2.5 & 180 & 450 \\
& & & & & Total & $\mathbf{2 4 4 6}$ \\
\hline
\end{tabular}

\subsection{Current Loads}

Table 8: Data for lighting

\begin{tabular}{lllllll}
\hline No & Equipments & Quantity & $\begin{array}{l}\text { The } \\
\text { power } \\
\text { unit } \\
{[\mathbf{k W / h}]}\end{array}$ & $\begin{array}{l}\text { Overall } \\
\text { power }[\mathbf{k W}]\end{array}$ & $\begin{array}{l}\text { Annual } \\
\text { hours of } \\
\text { use }\end{array}$ & $\begin{array}{l}\text { Annual } \\
\text { cons u } \\
\text { mption } \\
{[\mathbf{k W h}]}\end{array}$ \\
\hline 1 & $\begin{array}{l}\text { CFL bulbs in day } \\
\text { care }\end{array}$ & 0.011 & 0.033 & 1825 & 60.225 \\
2 & $\begin{array}{l}\text { CFL bulbs in } \\
\text { bedroom }\end{array}$ & 0.011 & 0.011 & 185 & 2.035 \\
3 & $\begin{array}{l}\text { CFL bulbs in } \\
\text { bathroom }\end{array}$ & & 0.011 & 0.054 & 185 & 9.99 \\
\hline
\end{tabular}




\begin{tabular}{|c|c|c|c|c|c|c|}
\hline 4 & $\begin{array}{l}\text { CFL bulbs in the } \\
\text { corridor }\end{array}$ & 1 & 0.011 & 0.011 & 365 & 4.015 \\
\hline 5 & $\begin{array}{l}\text { CFL bulbs in the } \\
\text { kitchen }\end{array}$ & 2 & 0.011 & 0.022 & 730 & 16.06 \\
\hline \multirow[t]{2}{*}{6} & $\begin{array}{l}\text { CFL bulbs in the } \\
\text { terrace }\end{array}$ & 1 & 0.011 & 0.011 & 90 & 0.99 \\
\hline & & & & & & 93.315 \\
\hline
\end{tabular}

\subsection{Use Of Liquid Petroleum Gas (Lpg)}

Annual expenses with LPG in a residential dwellings in Pristina, spent 12-14 with LPG bottles, worth 2 euros.

Table 9: Data for the Liquefied Petroleum Gas (LPG)

\begin{tabular}{|c|c|}
\hline \multirow{2}{*}{$\begin{array}{l}\text { An } \quad \text { LPG } \\
\text { Its weight in liters }\end{array}$} & 2 [euro] \\
\hline & 1 botlle $=2.9850[$ liters $]=2[$ euro $]$ \\
\hline Price per liter of LPG & 1 liter $=0.67[$ euro/liter $]$ \\
\hline \multirow{5}{*}{ Months of the year: 12} & $12 * 1 * 2.9850=35.820[$ liters $/$ year $]$ \\
\hline & $14 * 1 * 2.9850=41.79[$ liters/year $]$ \\
\hline & $35.820\left[\right.$ liters $/$ year] ${ }^{*} 0.67[$ euro/liter] $=23.99$ [euro/year] \\
\hline & $41.79[\text { liters/year }]^{*} 0.67[$ euro/liter] $=27.99$ [euro/year] \\
\hline & $\begin{array}{l}\text { So with LPG annual expenses have cost approximately } \\
24 \text { to } 28 \text { euros per year. Calculating the average cost } \\
\text { around } 26 \text { euros per year. }\end{array}$ \\
\hline - Overall total annual gas costs, & From 23.99 to 27.99 [euro/year] \\
\hline $\begin{array}{l}\text { - Number of proofreading skills } \\
\text { in refining the LPG }\end{array}$ & $12-14[$ bottle/year $]$ \\
\hline $\begin{array}{l}\text { - The value of the total amount } \\
\text { for an LPG bottle }\end{array}$ & 2.9850 liters \\
\hline $\begin{array}{l}\text { A bottle of LPG per month and } \\
\text { its price per liter }\end{array}$ & $2[$ euro $] / 0.67[$ euro $/ l]=2.9850[$ liters $]$ \\
\hline \multicolumn{2}{|l|}{$\begin{array}{l}\text { Average expenditures for the } \\
\text { past three years with LPG }\end{array}$} \\
\hline Use of LPG in a flat housing & $\begin{array}{l}\text { In the hous ehold sector, liquefied petroleum gas (LPG) } \\
\text { used for preparing various food standards for the } \\
\text { preparation of coffee, tea, water heating, etc. }\end{array}$ \\
\hline Saving energy & $\begin{array}{l}\text { With the use of LPG in a residential dwellings, has a } \\
\text { great saving of electricity, so the use of LPG in the } \\
\text { household, it is very cheap and usefulthan the use of } \\
\text { electricity at home. From this conclusion, it appears } \\
\text { that we have very great saving electricity, replacing it } \\
\text { with LPG for a family of three members and high } \\
\text { energy efficiency. }\end{array}$ \\
\hline I & GENERAL INFORMATION LPG \\
\hline
\end{tabular}

\subsection{Details For Calculation Of Different Scenarios}


Scenarios are taken for calculation:

1. Consumption, which are reported electricity bills and expenses for LPG,

2. Consumption state of comfort, which express the consumption of the apartment in the state in which,

3. Consumption after EE measures that said flat consumption, as implemented energy efficiency measures, and

4. Savings, which expresses the difference between the state of comfort and state standardized after implementation of EE measures.

Table 10: The data reported for the specific consumption and consumption data for standardized comfort

\begin{tabular}{|c|c|c|c|c|}
\hline & $\begin{array}{l}\text { Reported } \\
\text { cons umption } \\
\text { [kWh/year] }\end{array}$ & $\begin{array}{l}\text { The } \\
\text { situation of } \\
\text { comfort } \\
\text { [kWh/year] }\end{array}$ & $\begin{array}{l}\text { After } \\
\text { cons umption } \\
\text { meas ures } \\
\text { (EE) } \\
{[\mathrm{kWh} / \text { year] }}\end{array}$ & $\begin{array}{l}\text { Saving } \\
\text { [kWh/year] }\end{array}$ \\
\hline $\begin{array}{ll}\text { The } & \text { Liquefied }\end{array}$ & 496.8 & 496.8 & 496.8 & 0.0 \\
\hline Petroleum Gas (LPG) & & & & \\
\hline $\begin{array}{l}\text { Various consumers of } \\
\text { electricity }\end{array}$ & 3321.8 & 4389.32 & 4389.32 & 0 \\
\hline Energy for heating & & 4726.46 & 4371.18 & \\
\hline Total energy & 3818.6 & 9612.6 & 9257.3 & 355.3 \\
\hline $\begin{array}{l}\text { The object quadrature } \\
{\left[\mathrm{m}^{2}\right]}\end{array}$ & \multicolumn{4}{|c|}{ Specific Consumption $\left[\mathrm{kWh} / \mathrm{m}^{2} /\right.$ year $]$} \\
\hline $\mathrm{S}=62.7\left[\mathrm{~m}^{2}\right]$ & 60.9 & 153.3 & 147.6 & 5.7 \\
\hline
\end{tabular}

The table above shows that specific apartment has reported consumption of $60.9\left[\mathrm{kWh} / \mathrm{m}^{2} /\right.$ year $]$, while consumption is 153.3 standard for comfort $\left[\mathrm{kWh} / \mathrm{m}^{2} /\right.$ year], which means that in terms of missing flat comfort.

\section{Conclusions And Recommendations}

- Apartment is located on the seventh floor of an apartment building, consisting of eight floors, overlooking the south and surrounded by three sides with three other apartments. K bright enough picture and also to some extent by the warm rays of the sun, which fall directly into the windows of the apartment during the winter season;

- Apartment building is new construction, has insulated exterior wall thickness 10 [cm] and there is no need for additional investments and other, that have high energy saving;

- In calculating the electricity bills, it appears that energy costs are not high, because there saving and careful use of energy. Reason for energy saving, is that instead of electricity is also used liquefied petroleum gas (LPG) for household;

- With the use of LPG for household needs, has high saving electricity, based on the prices of LPG, electricity prices for $[\mathrm{kW}]$ and the time of their use in preparation of food and heat;

- Another trigger energy saving is the reason that from 11:00 until 17:00 stopped several electric and LPG, besides a fridge, a freezer and electric boiler are about 24 hours in the grid;

- Based on the above points and findings in electricity bills, it appears that there is roomconform to energy saving. So power consumption to the masses is 153.3 [kWh/year], and then pick measures 147.6 [kWh/year], so consumption is 5.7 [kWh/year].

\section{References}

1. Gashi N: Kalkulimi i konsumit të energjisë në banesë. Byro Projektuese - Studio Links 4, Prishtinë 2013; 
2. Berisha A: Planimetia e banesës dhe objektit banesor, për hyerjet A dhe B në Lagjen Kalabria e Re në Prishtinë - Kompania Fitorja - Ferizaj 2009;

3. Rregullore Teknike 03/2009 Për Energji Termike dhe Mbrotje Termike në Ndërtesa, MMPH Qeveria e Kosovës, Prishtinë 2009;

4. Rregullorja Nr. 01/2012 për Themelimin dhe Funksionimin e Komisionit për certifikim të auditorëve dhe menaxherëve të energjisë, MZHE;

5. Udhëzim Administrativ Nr. 14/2012 për Promovimin e Efiçiencës së Energjisë të përdoruesit fundor dhe shërbimet energjetike, MZHE, Prishtinë 2012;

6. Islami B: Stathis V. Metodologjia e auditimit të energjisë në Ndërtesa Publike, Trajnim profesional për auditim të energjisë - Danish Energy Management\&Kantor, Prishtinë 2010;

7. Qelaj M: Trajnim professional: Auditimi i Energjisë në Ndërtesat e Sherbimit Publik, Danish Energy Management\&Kantor, Prishtinë 2010;

8. KEDS, Faturat e energjisë elektrike për tri vitet e fundit 2010-2013, Prishtinë 2013. 